DOI http://dx.doi.org/10.18551/rjoas.2016-02.06

\title{
HOUSEHOLD FOOD SECURITY BASED ON PATTERN OF MIX FARMING IN KUPANG, EAST NUSA TENGGARA, INDONESIA
}

\author{
Silverius Leki \\ Post Graduate Program of Agriculture, Faculty of Agriculture, \\ University of Brawijaya, Indonesia \\ Faculty of Agriculture, University of Nusa Cendana, Penfui, Indonesia \\ E-mail: sil leki@yahoo.co.id \\ Nuhfil Hanani, Rini Dwiastuti, Budi Setiawan \\ Faculty of Agriculture, University of Brawijaya, Malang, Indonesia \\ E-mail: nuhfil.fp@ub.ac.id, dwiastuti fpub@yahoo.com, budis13@yahoo.com
}

\begin{abstract}
The purpose of the study is to describe pattern of mix farming that is managed householdally as well as to analyze the level of Household food security based on the pattern of mix farming. Stratified cluster method is used to determine the setting of the study, while simple random sampling is used to decide 114 households being involved in the study. The findings of the study show that there are three types of mix farming pattern managed Householdally, namely (1) mix farming combining crops and plantation, (2) mix farming combining crops and livestock, and (3) mix farming combining crops, plantation and livestock. Household mix farming has low food security with the average level of energy consumption per capita per day of $2,107 \mathrm{kcal}$ and protein consumption of 48.33 grams. The level of food security of the Household mix farming combining crops, plantation and livestock is higher than the ones combining crops and plantation as well as combining crops and livestocks. In the pattern of mix farming combining crops, plantation and livestock, there are 98.36\% households that have achieved food security. On the other hand, in the pattern of mix farming combining crops and plantation, there are $87.50 \%$ household that achieved food security, while $62.07 \%$ of the households in the pattern of mix farming combining crops and livestock that have achieved food security.
\end{abstract}

\section{KEY WORDS}

Consumption, insecurity, energy, farming system, crops, livestocks, timor.

Household food security is a condition where a household and its members get sufficient food and can live a healthy, active and productive life on a regular basis. Food security has such complex dimensions that in order to measure food security one should simplify its complexity by emphasizing on three different, inter-related dimensions i.e., food availability, household access to the food and food utilization by individuals (Weingärtner, 2006). According to Gross et al. (2000), food security consists of four major subsystems namely food availability, food access, food utilization and food stabilization. Meanwhile, nutriotional status is the outcome of food security that represents individual's quality of life. Zero cases of starvation and malnutrition are indicators of good public nutritional status. (Bentaya, 2006; Hanani, 2012).

Until now, Indonesia still encounters problems related to food security. Food crisis has yet been found in various places in Indonesia including East Nusa Tenggara (Food Security Council and World Food Programme, 2009). The Food Security and Vulnerability Atlas East Nusa Tenggara shows that in Kupang there are $60.87 \%$ regions that are vulnerable to food scarcity while the remaining $39.13 \%$ has achieved food security (the Regional Government of East Nusa Tenggara, 2010). The results of the data analysis of the food ingredient scale by the Food Security and Counseling Office of East Nusa Tenggara (2013) reveal that there are $3,832 \mathrm{kcal} / \mathrm{capita} /$ day available energy for the people living in East Nusa Tenggara, meanwhile the average calori and protein consumptions per capita of the East Nusa 
Tenggara villagers are $1,836.22 \mathrm{kcal}$ and 48.33 grams. It means eventhough the available energy has exceeded the minimum standard of $2,200 \mathrm{kcal} /$ capita/ day, the energy and protein consumptions can only reach $91.81 \%$ and $92.94 \%$ out of the recommended standardized need.

In the effort to achieve food security, each household tries to make use of the resources it has. The 2013 agriculture census shows there are 53,011 agricultural households in Kupang (Central Bureau Statistics of Kupang, 2013). Agricultural household has run mix farming combining crops and livestock from generation to generation. Mix farming is frequently defined as planting various different types of crops and as the consequence putting aside other activities like livestock and fishery (Rao et al., 2004). According to Moenandir (2004), mix farming is an agricultural system that involves crops, animals, and/or perennials.

Kieft (2007) stated that Farmers on Timor have the skills and the capacity to develop and conserve different varieties of staples. This allows them to grow a variety of crops which can cope with a harsh climate and poor soils. The finding of Amareko (1988)'s study shows that households plant different types of crops and keeps different types of livestock to run mix farming system. The combination and synergy between crops and livestock in mix farming minimize risk and uncertainty in production and marketing, stabilize farmer's household income, and is environmentally friendly (Rao and Brirthal, 2008; Burgers et al., 2005). Considering its benefits and advantages, mix farming is considered as the strategy to develop food security (Guritno, 2011; and Saliem et al., 2006).

It is mentioned previously that Kupang has always encountered problems related to food security. In general, the level of food availability has been sufficient; however there are households and individuals who do not have access to sufficient food. A lot of agricultural households produce food yet are lacking of food. On the other side, mix farming system is able to improve food security. According to Ellis (1988), agricultural household produce food in order to fulfill family need. Therefore, it is vital to conduct a study of which purpose is to describe pattern of Householdally run mix farming and also analyze the level of Household food security based on the pattern of mix farming.

\section{MATERIALS AND METHODS}

The setting of the study is a village called "Tesbatan" located in the region of "Amarasi" and another village called "Camplong II" located in the region of "Fatuleu" Kupang, East Nusa Tenggara. Stratified cluster method is used to determine the setting of the study. "Tesbatan" represents villages that have achieved food security while "Camplong II" represents villages that encounter food insecurity problem based on the food security criteria from the East Nusa Tenggara food ingredient scale. In addition, random sampling is carried out to select the households that become the respondents of the study; the respondents of the study are $10 \%$ of the total households in each of the villages. The total respondents are 114 households consist of 37 households from "Tesbatan" village and 77 households from "Fatuleu" village.

The measurement of the Household food security is carried out using the nutritional status approach (Hanafie, 2010; Hanini, 2010) that is to use nutritional adequacy rate and energy adequacy rate as parameters. The 2013 Decree of the Ministry of Health number 75 states that the nutritional adequacy rate is $2,150 \mathrm{kkal}$ and protein consumption is 57 grams per person per day on the level of consumption (The Ministry of Health, 2013). Furthermore, the Food and Agriculture Organization (FAO, 2003) categorizes food security based on energy consumption level. It is categorized as food security when energy consumption is more than $90 \%$ of the recommended number. It is categorized as mild food insecurity when energy consumption is between $81-90 \%$. When energy consumption is between $70-80 \%$, it is considered moderate food insecurity. Finally, when energy consumption is lower than $70 \%$, it is categorized as severe food insecurity.

The basis for the measurement of total energy and protein consumption is the amount of consumed food that is the result of household surveys using 1x24 hour recall method with 
nutritional content data from the List of Food Composition formulated by Hardinsyah and Briawan (1990):

1) Energy and Protein Food Conspumtion in Each Type of Food:

$\mathrm{AECj}=[\mathrm{Wj} \times \mathrm{Ej} / 100 \times(\mathrm{PCFj} / 100)] / \mathrm{NFM}$

$A P C j=[W j \times P j / 100 \times(P C F j / 100)] / N F M$

Description:

$A E C j$ = Actual Energy Consumption from $\mathrm{j}$ Type of Food (kcal/cap/day);

APCj = Actual Protein Consumption from j Type of Food (gram/kap/hr);

$\mathrm{Wj}=$ Weight of $\mathrm{J}$ Type of Food (gram);

$\mathrm{Ej}=$ Energy Content $/ 100$ grams of $\mathrm{j}$ Type of Food;

$\mathrm{Pj}=$ Protein Content $/ 100$ grams of $\mathrm{j}$ Type of Food;

$\mathrm{PCFj}=$ Percentage of Consumed $\mathrm{J}$ Type of Food;

NFM = Number of Family Members (people);

$\mathrm{j}=$ Type of Food.

2) Total Energy Consumption and Protein:

$$
\begin{aligned}
& \mathrm{TEC}=\sum_{\mathrm{p}=1}^{9} \mathrm{AEC}_{\mathrm{p}} \\
& \mathrm{TPC}=\sum_{\mathrm{p}=1}^{9} \mathrm{APC}_{\mathrm{p}}
\end{aligned}
$$

Description:

TEC = Total of Actual Energy Consumtion of Entire Food Group;

TPC = Total of Actual Protein Consumtion of Entire Food Group;

$A E C p=$ Actual Energy Consumption in p Food Group;

$A P C p=$ Actual Protein Consumption in $p$ Food Group.

Comparing the total actual nutritional consumption and recommended nutritional consumption is carried out in order to find out the adequacy of nutrient consumption.

\section{RESULTS AND DISCUSSION}

Mix Farming Condition. Mix farming is the system of agriculture where crops, plantation and/or livestock are managed together in one household business.

\begin{tabular}{|c|c|c|c|c|c|}
\hline No. & Type of Crops & Percentage & No. & Type of Crops & Percentage \\
\hline 1 & Corn & 98.25 & 14 & Chili & 4.39 \\
\hline 2 & Paddy & 35.09 & 15 & Mustard & 2.63 \\
\hline 3 & Cassava & 72.81 & 16 & Eggplant & 10.53 \\
\hline 4 & Sweet Potato & 2.63 & 17 & Tomato & 16.67 \\
\hline 5 & Peanuts & 57.89 & 18 & Mango & 45.61 \\
\hline 6 & Green Bean & 10.53 & 19 & Jackfruit & 16.67 \\
\hline 7 & Cowpea & 60.53 & 20 & Papaya & 31.58 \\
\hline 8 & Turis & 20.18 & 21 & Banana & 55.26 \\
\hline 9 & Spinach & 1.75 & 22 & Coconut & 46.49 \\
\hline 10 & Onions & 1.75 & 23 & Cashew & 64.91 \\
\hline 11 & Bean & 12.28 & 24 & Areca Nut & 4.39 \\
\hline 12 & Long bean & 6.14 & 25 & Betel & 3,51 \\
\hline 13 & Pumpkin & 63.16 & & & \\
\hline
\end{tabular}

Table 1 - Level of Household Participation in Ensuring Plants

Source: Primary Data. 
The types of crops and livestock in mix farming system are various and different from one household to another. The result of identification found 25 types of crops and 4 livestocks being planted and taken care of in the mix farming system. Table 1 shows the level of household participation in ensuring plants in the mix farming system.

The farmers' households plant various types of corps and long-lived plants altogether. In the rainy season, the farmers plant some corps i.e. paddy, corn, sweetpotato, beans and vegetable suitable with the local condition and local wisdom. One of the local wisdoms is called "salome," which stands for "satu lubang rame-rame" where the farmers grow corn, beans and squash seeds in one spot. The purpose is to minimize some risks so when one of the seeds cannot grow, the other two can still grow and be harvested as food. "Salome" also saves cost and labor to make the stakes for the cowpeas. Other methods are mixed intercropping, row intercropping and relay intercropping (Mudita, 2013). The pattern of intercropping is applied as the effort to divide the risk of crop failure among different types of crops so that one type of crop cannot be harvested, the other types can still be harvested. In other words, the purpose of intercropping is to guarantee food security (Lithourgidis et al., 2011).

Corn is the major type of crop planted by the farmer households. $98.25 \%$ of them grow corn. It is in line with Ormeling (1957) which states that corn is a type of staple food that is subcitently managed. Even though corn is not originated from Timor, the area has dry climate suitable for growing corn and the crop matches the sociocultural condition of the area. According to Fowler (2005), corn was brought by the Colony around 400-500 years ago. The Dutch then promoted corn to overcome food stravtaion and it was quickly adopted by people of the West part of Timor (Fox, 1977; McWilliem, 2000). Fox (1995) states that although farmer plant maize as a major staple, a wide variety of other crops must also be relied upon to maintain food security. On the other hand, ricefield is pretty limited; only $35.09 \%$ of the households grow paddies. It is caused by limited area suitable for ricefields.

More households in the two villages grow cassava than sweetpotato since intercropping method in wide areas (Mudita, 2013). Relatively high percentages of the households, $60.53 \%$, grow cowpeas, followed by peanuts and turis. Beans are considered as important type of crops because they are the sources of protein as well as household income.

The types of vegetables most frequently grown in the rainy season are pumpkin and corn. Besides its fruit, pumpkin shoots are consumed as vegetables. Increasing consumption of organic vegetable causes high demand of pumpkin shoots in Kupang. Each household picks the pumpkin shoots 2 or 3 times a day for both consumption and being sold.

Plantation crops being grown involve coconut and cashew. Cashew has high contribution to the household income. The areca nut and betel plantation are relatively limited because they can only be grown in areas near water source. Therefore, the areca nut and betel are grown by the households who own the pieces of land near the river. There is such a high demand of areca nut and betel by the society. The majority of the people from West Timor consume both betel and areca nut. Besides that, these crops are the means of communication and parts of tradition. The villagers of Timor can survive the lack of rice but they will not survive the lack of betel and areca nut.

Besides growing some crops, the household also keeps some livestock such as chicken, goat and cow. There are $62.28 \%$ of the household that keep cows with the 2.12 average of cows per household. The cows roam freely in the meadows. However, some farmers start to tie their cows and keep their cows intensively in their yards.

$63.16 \%$ of the households keep pigs with the 2.01 average of pigs per household. Pig is considered as the important source of income and has high reputation in the sociocultural aspect of the people of Timor. Socioculturalwise, pig is sometimes more expensive than other livestocks. Different from pig, the number of goats in the area is relatively small. Only $9.65 \%$ of the household has goats with the 0.95 average of goat per household. $71.93 \%$ of the household has free-range chicken with the 11.01 average of free-range chicken per household. The system the farmers use to keep their livestock is simplified one and therefore 
some improvement should be made to get more optimum result and take advantage of the available resource (Nulik and Hau, 2006).

Based on the type of crops, plantation and livestocks, the pattern of mix farming in Kupang, East Nusa Tenggara can be categorized into three groups i.e., (1) mix farming combining crops and plantation, (2) mix farming combining crops and livestock, and (3) mix farming combining crops, plantation and livestock.

$21.05 \%$ of the household manage the first group of mix farming pattern, while the percentages of the ones that manage the second and third patterns of mix farming are $25.44 \%$ and $53.51 \%$ respectively. Different types of crops and livestock the households have in each of the patterns will affect the production of food and eventually influence Household food security.

Energy and Protein Consumption. Energy consumption per capita per days in the mix farming households is $2,107 \mathrm{kkal}$. It means the energy consumption has just reached $98 \%$ of the standardized normative energy sufficiency. The level of energy consumption is higher than the average energy consumption of people of East Nusa Tenggara of 1,833.37 Kcal (Food Security and Counseling Office of East Nusa Tenggara. 2014). On the other hand, the average protein consumption is 48.33 grams per capita per day that means the protein consumption has just reached $84.79 \%$ out of the recommended normative number. The findings of the study are in accordance to those of Asmara et al. (2009) which state that the average of energy consumption in "Kepuh Kembang" village is still less than the standardized energy need, eventhough the gap between them is relatively close.

Table 2 shows the contribution of each food group towards energy and protein consumption. Grains have $73.84 \%$ contribution toward energy consumption and $60.83 \%$ toward protein consumption. Other groups give relatively small contributions toward the total of energy and protein consumptions. It shows that the households consume more carbohydrates than other substances. Being full is the main consideration for the villagers about the food they consume. They have yet considered the nutritional balance of they have to fulfill and the source of the nutritional balance is the food they consume.

Table 2 - Energy and Protein Consumption per Capita per Day based on Food Group

\begin{tabular}{lllll}
\hline \multirow{2}{*}{ Food Group } & \multicolumn{2}{c}{ Energy Consumption } & \multicolumn{2}{c}{ Protein Consumption } \\
\cline { 2 - 5 } & Kcal & $(\%)$ & 29.4 & $(\%)$ \\
\hline Grains & $1,555.70$ & 73.84 & 0.9 & 1.86 \\
\hline Root Vegetables & 83.34 & 3.96 & 3.68 & 7.6 \\
\hline Dairy & 57.5 & 2.73 & 10.43 & 21.59 \\
\hline Beans & 84.87 & 4.03 & 2.62 & 5.42 \\
\hline Vegetables & 57.43 & 2.73 & 0.66 & 1.36 \\
\hline Fruits & 72.82 & 3.46 & 0.55 & 1.14 \\
\hline Oily Fruits & 57.32 & 2.72 & 0.11 & 0.22 \\
\hline Oil and Fat & 88.79 & 4.21 & 0.00 & 0.00 \\
\hline Sugar & 49.21 & 2.34 & 48.33 & 100 \\
\hline Total & $2,106.99$ & 100 & & \\
\hline
\end{tabular}

Source: Primary Data.

Beans have $4.03 \%$ contribution toward energy consumption and $21.59 \%$ towards protein consumption. The high contribution the beans have toward the energy and protein consumption can be traced back to the high percentage of households that grow beans; the farmers consume some of the beans they grow. Dairy product which is expected to have high contribution to protein consumption sufficiency can only have $7.60 \%$ contribution toward protein consumption. The cause is the low percentage of dairy consumption since the price of the dairy product is relatively more expensive compared to other food groups and there is financial problem taking place in the households (Dwiastuti, 2008). Besides that, livestock business has yet given real contribution to food consumption sufficiency. The household dairy consumption is relatively small. The analysis shows the dairy consumption of the household livestock business is approximately $8.85 \%$ of the total dairy consumption of the household. The percentage shows that instead of taking the meat or the milk of the livestock 
as their own consumption, the farmers keep the livestock for social prestige or as future investment to be sold to pay for the cost of their children education.

Food Security based on Pattern of Mix Farming. Food security is a condition where each individual, regardless of the time, have physical, social and economic access to sufficient, safe and nutritious food to fulfill their need of food and preferences of food so that the individual can live an active, healthy life (Food and Agriculture Organization, 1996). In the study, the measurement of food security is carried out using nutrient sufficiency approach with the Energy Sufficiency Rate and Protein Sufficiency Rate as the parameters.

Energy consumptiol level varies based on the pattern of mix farming. The mix farming combining crops, plantation and livestock (the $3^{\text {rd }}$ pattern) has the highest energy consumption level, followed by the one combining crops and plantation (the $1^{\text {st }}$ pattern), and the mix farming combining crops and livestock (the $2^{\text {nd }}$ pattern) has the lowest energy consumption level. The average energy consumption level per capita per day in the mix farming pattern combining crops, plantation and livestock is 2,136 kcal with the 1,693 kkal as the lowest and 2,816 as the highest level. Compared to the normative energy consumption sufficiency rate, the level of energy consumption in the mix farming pattern has achieved $99.35 \%$ of the normative rate. The average energy consumption level per capita per day in the mix farming pattern combining crops and plantation (the $1^{\text {st }}$ pattern) is $2,133 \mathrm{kcal}$ with the $1,476 \mathrm{kkal}$ as the lowest and 2,651 as the highest level.The average energy consumption has achieved $99.20 \%$ of the normative rate. In the mix farming pattern combining crops and livestock, the average energy consumption per capita per day is 2,051 kcal with 1,466 kkal as the lowest and $2,731 \mathrm{kkal}$ as the highest or $95.38 \%$ of the normative rate.

Similar to the energy consumption, the households that run the mix farming pattern combining crops, plantation and livestock have the highest level of protein consumption that is 49.33 grams. Protein consumption for the mix farming pattern combining crops and plantations is 47.49 grams and that for the mix farming pattern combining crops and livestock is 45.76 grams. The numbers are higher than the average protein consumption of the East Nusa Tenggara villagers of 45.85 grams. However, the protein consumption of the households is still lower than the average protein consumption of people living in the cities of East Nusa Tenggara that is $\mathbf{5 2 . 8 4}$ grams (Food Security and Counseling Office of East Nusa Tenggara, 2014). When compared to the normative sufficient rate, the protein sufficiency rate in the mix farming combining crops and plantation (the $1^{\text {st }}$ pattern) is $83.32 \%$ while those in the $2^{\text {nd }}$ and $3^{\text {rd }}$ pattern of mix farming are $80.28 \%$ and $86.55 \%$ respectively. It shows that protein consumption level in the pattern of mix farming combining crops, plantation and livestock is the highest one. It is closely related to the pattern of agricultural business the households run. In the third pattern of mix farming, the farmers plant crops and plantation as well as keep the livestock so that they have adequate amount of food supply from their business. Besides that, they have higher income that allows the farmers to have better access to food compared to other households.

The FAO established some categories of the level of food security based on energy consumption. When a household consumes less than $70 \%$ calories of the normative rate, the household is considered as one with severe food insecurity. If a household consumes around $70-80 \% \%$ calories of the normative rate, the household is considered as one with moderate food insecurity. Furthermore, when a household consumes around $81-90 \%$ calories of the normative rate, the household is considered as one with mild food insecurity. Finally, a household has achieved food security when its energy consumption reaches more than $90 \%$ of the normative rate. Based on the findings of the study there are $86.84 \%$ households that has successfully achieved food security, $0.88 \%$ households with severe food insecurity, $4.39 \%$ households with moderate food insecurity and $7.89 \%$ households with mild food insecurity.

Table 3 shows that $98.36 \%$ households categorized as households with food security are the ones with the mix farming pattern combining crops, plantation and livestock. Moreover, $87.50 \%$ households categorized as households with food security are the ones with the mix farming pattern combining crops, and plantation while $62.50 \%$ households with mix farming pattern combining crops and livestock are considered one successfully achieved 
food security. The percentages show that the more varied plants a household grows and livestock it keeps, the higher energy consumption it has.

Table 3 - Level of Food Security based on Pattern of Mix Farming

\begin{tabular}{lccc}
\hline \multirow{2}{*}{ Food Security } & \multicolumn{3}{c}{ The pattern of mix farming } \\
\cline { 2 - 4 } & $\begin{array}{c}\text { Pattern 1: combining } \\
\text { crops and plantation }\end{array}$ & $\begin{array}{c}\text { Pattern 2: combining } \\
\text { crops and livestock }\end{array}$ & $\begin{array}{c}\text { Pattern 3: combining } \\
\text { crops, plantation, livestock }\end{array}$ \\
\hline Severe Food Insecurity & 0.00 & 3.45 & 0.00 \\
\hline Moderate Food Insecurity & 8.33 & 6.90 & 1.64 \\
\hline Mild Food Insecurity & 4.17 & 27.59 & 0.00 \\
\hline Food Security & 87.50 & 62.07 & 98.36 \\
\hline
\end{tabular}

Source: Primary Data.

The level of food security of the three patterns of mix farming is closely related to the number of plants the farmers grow and/or the number of livestock they keep. The more plants the farmers grow and/or livestock they keep the better access to and supply of food the farmers have. The finding is in line with that of Saliem et al. (2006) and Fagi and Partohardjono (2004) that there is acorrelation between food security and business diversification. Meanwhile, low food security level in the households with mix farming pattern combining crops and livestock can be traced back to the fact that the households run small-scale business. As the effect, their small-scale business cannot fulfill the need of their households.

The level of food security of the study is better than one in Yoris (2013)'s study conducted in West Maluku where the percentage of the respondents' food security is only $23.33 \%$. The causes of the different findings are food production that influences households' food availability, as well as physical and economic access to food (Awasthi and Singh, 2010). Food availability and accessibility alone cannot guarantee food security. Food security is also related to carefully prepared food utilization to fulfill the need of nutritions of a household (Barrett, 2010).

Based on the elaboration, it can be concluded that the average energy and protein consumption in the households with mix farming system that combines crops, plantation and livestock are the highest of the three mix farming pattern.

\section{CONCLUSION}

The pattern of the mix forming run Householdally by the households can be divided into three groups i.e., (1) mix farming combining crops and plantation, (2) mix farming combining crops and livestock, and (3) mix farming combining crops, plantation and livestock.

The agricultural household has low food security with the average energy consumption per capita per day of $2,107 \mathrm{kcal}$ and protein consumption per capita of 48.33 grams.

The level of food security of the Household mix farming combining crops, plantation and livestock is higher than the ones combining crops and plantation as well as combining crops and livestocks. In the pattern of mix farming combining crops, plantation and livestock, there are $98.36 \%$ households that have achieved food security. On the other hand, in the pattern of mix farming combining crops and plantation, there are $87.50 \%$ household that achieved food security, while $62.07 \%$ of the households in the pattern of mix farming combining crops and livestock that have achieved food security.

\section{RECOMMENDATION}

In order to develop Household food security, intensification of agriculture business should be done to increase agricultural production so that there are more foods available for household consumption.

Since mix farming that combines crops, plantations and livestock has high level of food security, there should be an effort to develop agriculture business diversification to increase production and household income so that each household can have access to sufficient food. 


\section{REFERENCES}

1. Amareko, S. (1988). Socio-Economic Analysis at Various Subsystems Farmers in Kupang district. Kepas Nusa Cendana University, Kupang.

2. Asmara, R., N. Hanani dan I. A. Purwaningsih. (2009). The Effect of Economic and Non Economic Factors in Foof Diversification Based on Desirable Diatary Pattern (case Studi at Klagen Orchard, Kepuh Kembang Village, Paterongan Sub Distict, Jombang Region). Agrise IX (1) January 2009, 19-31.

3. Awasthi M.K. and S. Singh. (2010). System Analysis of Food Security Situation in India. Journal of Food Security. 1 (1), January- June, 2010, 24-32.

4. Barrett, C. (2010). Measuring food insecurity. Science, 327 (5967), 825-828.

5. Bentaya, M. G. (2006). Instruments for the Assessment and Analysis of the Food and Nutrition Security Situation at Micro and Meso Level. In Klaus Klennert (Ed.) Achieving Food and Nutrition Security Actions to Meet the Global Challenge A Training Course Reader. InWEnt, Feldafing - GTZ, Eschborn - DWHH, Bonn, Germany: 87-114.

6. Burgers, P., Ketterings, Q. M., Garrity, D. P. (2005). Fallow management strategies and issues in Southeast Asia. Agriculture, Ecosystems and Environment 110, 2005, 1-13.

7. Central Bureau Statistics of Kupang. (2014). Census of Agriculture 2013 in Kupang Regency, Kupang.

8. Dwiastuti, R. (2008). Skenario Kebijakan Diversifikasi Konsumsi Pangan Berbasis Perilaku Rimahtangga dan Kelembagaan Lokal. Collaboration between Research and Development Bureau of the Department of Agriculture and the Institute of Research and Community Service of Brawijaya University Malang.

9. Ellis, F. (1988). Peasant Economics: Farm Hiusholds and Agrarian Develompment Analysis. Fifth Edition. Jhon Wiley and Sons Inc. New York.

10. Fagi, A.M. dan S. Partohardjono. (2004). Diversifikasi Usahatani Berorientasi Padi in Kasryono et al (Eds). Ekonomi Padi dan Beras. Agricultural Research and Development Bureau, Jakarta.

11. Food and Agriculture Organization (FAO). (2003). Proceeding Measurement and Assesment of Food Devrivation and Undernutrition. International Scentific Symposium. Rome, 26 - 28 Juni 2002.

12. Food and Agriculture Organization (FAO). (1996). The Rome Declaration on World Food Security and World Food Summit Plan of Action, World Food Summit, 13-17 November 1996. Rome.

13. Food Security and Counseling Office of East Nusa Tenggara. (2013). Neraca Bahan Makanan Provinsi NTT Tahun 2011-2012. Kupang.

14. Food Security and Counseling Office of East Nusa Tenggara. (2014). Analisis Pola Konsumsi Pangan Penduduk Nusa Tengga Timur 2013. Kupang.

15. Food Security Council Department of Agriculture and the World Food Programme. (2009). Food Security and Vulnerability Atlas of Indonesian 2009. Jakarta.

16. Fowler. (2005). Why Maize is a Sacred Palm. Sosial History and Agrarian Change on Sumba. Journal of Etholobiology 25(1), 39-57.

17. Fox J.J. (1995). Social history and government policy of agricultural development in Eastern Indonesia. Paper presented at the International Conference on Agricultural Development in semi-arid Areas of East Nusa Tenggara, Kupang: 10-16 December 1995.

18. Fox, J. (1977). Harvest of Palm: Ecological Change in Eastern Indonesia. Cambridge: Harvard University Press.

19. Gross, R. Schoeneberger, H., Pfeifer, H., Preuss, H. (2000). The Four Dimension of Food and Nutrition Security: Difinitions and Concepts. SCN News, 20, 20-25

20. Guritno, B. (2011). Pola Tanam Di Lahan Kering. Brawijaya University Press Malang.

21. Hanafie, R. (2012). Diversifikasi Konsumsi Pangan Sebagai Komponen Utama Ketahanan Pangan. http://widyagama.ac.id. Retrieved on 10 April 2014.

22. Hanani, N, (2012). Strategi Enam Pilar Pembangunan Ketahanan Pangan. Inaugural Speech in Agricultural Economy in the Faculty of Agriculture Brawijaya University. Malang. 
23. Hardinsyah dan Dodik Briawan. (1990). Penilaian dan Perencanaan Konsumsi Pangan. Jurusan Gizi Masyarakat dan Sumberdaya Keluarga. Department of Community Nutrition and Family Resources. Faculty of Agriculture, Bogor Agricultural University, Bogor

24. Kieft, J. (2007). Indigenous variety development in food crops strategies on Timor: their relevance for in situ biodiversity conservation and food security. Institute of Indonesia Tenggara Studies (East Nusa Tenggara Studies). IITS Publications.Open Sources.

25. Lithourgidis A.S., Dordas, C.A., Damalas, C.A., and Vlachostergios,D.N. (2011). Annual Intercrops: an Alternative Pathway for Sustainable Agriculture. Australian Journal of Crop Science, 5(9), 396-410.

26. McWilliam, A. (2000). A Plague on Your House? Some Impacts of Chromolaena odorata on Timorese Livelihoods. Human Ecology, 28 (3), 2000, 451-469.

27. Moenandir, J, (2004). Prinsip Menyukseskan Produksi Pertanian. Faculty of Agriculture, Brawijaya University. Bayumulia Publishing. Malang.

28. Mudita, I.W. (2013). Pemetaan Pangan Lokal di Pulau Sabu Raijua, Rote Nadao, Lembata dan Dataran Timor Barat. Pikul Association and Oxfam, Kupang.

29. Nulik, J., D.K. Hau. (2006). Kajian System dan Model Integrasi Tanaman dan Ternak Di Lahan Pekarangan. Dalam Prosiding Seminar Nasional. Komunikasi Hasil-hasil Penelitian Bidang Tanaman Pangan, Perkebunan dan Peternakan dalam Sistem Usahatani Lahan Kering. Assessment Institute for Agricultural Technology and Developmet, Bogor, 505-515.

30. Ormeling, F. (1957). The Timor Problem. A Geographical Interpretation of an Underdeveleped Island. Djakarta \& Graningen: J.B.Wolters.

31. Rao, P. and PS. Birthal. (2008). Livestock in Mixed farming Systems in South Asia. National Centre for Agricultural Economics and Policy Research,New Delhi, India; International Crops Research Institute for the Semi-Arid Tropics. Patancheru, Andhra Pradesh, India.

32. Rao, P.P., Birthal, P.S., Joshi, P.K. (2004). Diversification towards High Value Agriculture Role of Urbanisation and Infrastructure. Economic and Political Weekly June 30, 2006, $2747-2753$.

33. Saliem H.P., Sumaryanto, G.S. Hardono, H. Mayrowani, T.Bastuti, Y. Marisa dan D. Hidayat. (2006). Diversification Households In Support of Food Security and Poverty Reduction in Indonesia. Center of Socio-Economic Analysis and Agricultural Policy. Department of Agriculture.

34. The Ministry of Health. (2013). The 2013 Regulation of the Ministry of Health Number 75 about the Recommended Nutrient Sufficient Level for Indonesian.

35. The Regional Government of East Nusa Tenggara. (2010). Food Security and Vulnerability Atlas of East Nusa Tenggara 2010. Food Security Council Department of Agriculture and the World Food Programme. Kupang.

36. Weingärtner, L. (2006). The Concept of Food and Nutrition Security. In Klaus Klennert (Ed.) Achieving Food and Nutrition Security Actions to Meet the Global Challenge A Training Course Reader. InWEnt, Feldafing - GTZ, Eschborn - DWHH, Bonn, Germany, 3-31.

37. Yoris, L. (2013). Community Food Consumption Pattern in District Lakor Southwest Maluku District. Agrinimal October 2013. 3 (2), 47-83. 